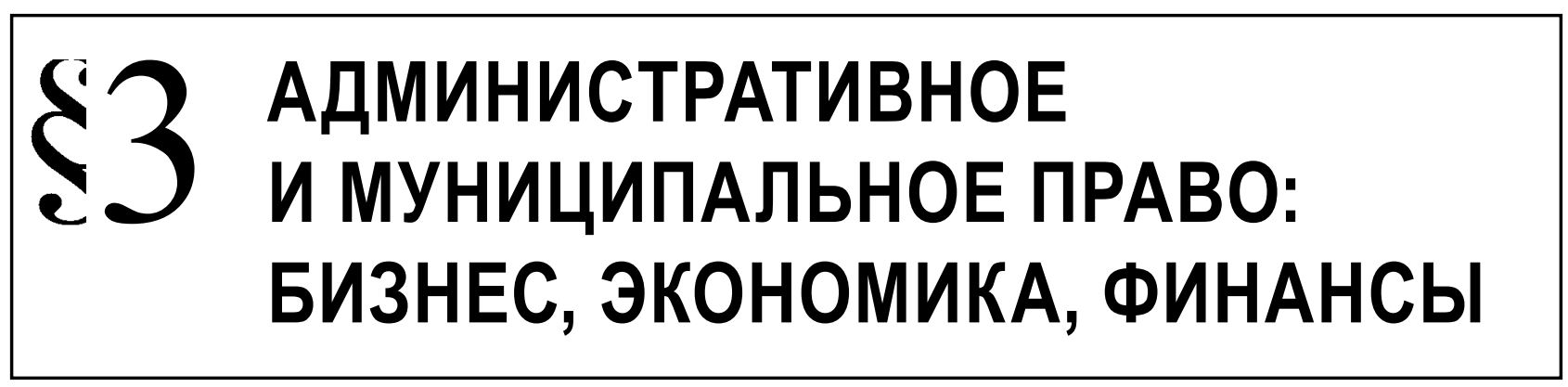

Косинов В.А.

\title{
УПРАЗДНЕНИЕ УНИТАРНЫХ ПРЕДПРИЯТИЙ КАК МЕРА ПО ПОВЫШЕНИЮ УРОВНЯ КОНКУРЕНЦИИ В РФ
}

Аннотация: Наделение функциями органов власти хозяйствующих субъектов - одна из основных проблем развития конкуренции на том или ином товарном рынке. Унитарные предприятия различных уровней получают различные преференции от государства благодаря чему получают полный контроль над тем или иным товарным рынком, не предпринимая при этом никаких усилий по созданию качественного и востребованного продукта.Однако, начиная с первых попыток реформировать систему управления государственной и муниципальной собственностью, предпринятых в 1999 г., ситуация изменилась несильно. В настоящее время для повышения уровня конкуренции, а также с целью создания равных условий для всех хозяйствующих субъектов, возникла необходимость в упразднении подобных предприятий, за исключением некоторых специфических сфер, ограничение доступа к которым обусловлено обеспечением безопасности страны.Для этого необходимо внесение соответствующих поправок в законодательство, так как более двадцати лет деятельность подобных предприятий не только тормозила экономическое развитие, но и приводила к существенным нарушениям конституционных положений о поддержке конкуренции и недопущении экономической деятельности, направленной на монополизацию и недобросовестную конкуренцию. Методологической основой исследования являются общенаучные и частно-научные методы познания общественных процессов. В процессе исследования использовались системно-структурный, сравнительно-правовой, исторический, логический, формально-юридический подходы. Их применение позволило автору исследовать рассматриваемую проблему во взаимосвязи, иелостности, всесторонне и объективно. Несмотря на сокращение численности подобных предприятий, в настоящее время количество нарушений антимонопольного законодательства со стороны подобных хозяйствующих субъектов только возросло. Особенно негативное влияние деятельность унитарных предприятий оказала на сферы ЖКХ, транспорта и садово-паркового хозяйства, в сфере бытовых услуг, в "ритуальном бизнесе», то есть тех срерах, которые требуют получения каких-либо согласований, разрешительной документации.По настоящее время неэффективное управление государственными и муниципальными активами с помощью унитарных предприятий не позволяет войти частным предприятия на те или иные рынки.

Ключевые слова: Конкуренция, государственные унитарные предприятия, муниципальные унитарные предприятия, рыночная экономика, антимонопольное регулирование, товарные рынки, государственная собственность, коммунальные услуги, реформирование, нарушения антимонопольного законодательства.

$\mathrm{C}$ огласно действующемузаконодательствуунитарным предприятием признается коммерческая организация, не наделенная правом собственности на закрепленное за ней собственником имущество. Имущество унитарного предприятия является неделимым и не может быть распределено по вкладам (долям, паям), в том числе между ра- ботниками предприятия (п. 1 ст. 113 Гражданского кодекса Российской Федерации (часть первая) // КонсультантПлюс).

При этом, законодатель ограничивает возможность создания таких предприятий указывая на то, что «в форме унитарных предприятий могут быть созданы только государственные и муници- 
пальные предприятия.» (п. 1 ст. 113 Гражданского кодекса Российской Федерации (часть первая) // КонсультантПлюс).

Первые попытки реформы унитарных предприятий были предприняты в 1999 году в рамках реформы управления госсобственностью с целью раскрытия финансовой деятельности и улучшения системы управления государственной собственностью.

14 ноября 2002 года вступил в силу Федеральный закон N 161-Ф3 «0 государственных и муниципальных унитарных предприятиях», регулирующий порядок создания, хозяйствования, реорганизацию и ликвидацию указанных предприятий.

По состоянию на конец 2004 г. количество подобных учреждений колебалось от 7 до 52 тысяч. Большинство из них практически не имело контроля со стороны государства. Менеджмент ФГУпов и ГУПов занимался коммерческой деятельностью, используя при этом муниципальное и государственное имущество, получая средства из бюджетов различных уровней, имея при этом различные льготы и не выполняя каких-либо общественно значимых для государства функций.

По мнению авторов реформы действующими должны были остаться только те предприятия, которые обеспечивали выполнение государственных функций. Инвентаризация ФГУ и ГУП должна была завершиться к осени 2004 г.

Сама же реформа была вызвана в первую очередь представлением о ГУПах как о «черных дырах» экономики, как на уровне субъекта, так и на уровне муниципалитета.

Однако, пока руководство страны разрабатывало политику акционирования унитарных предприятий, последние успели создать массу дочерних предприятий, которым передавали имущество. Потеряв какой-либо контроль со стороны собственника имущества, эти предприятия сохранили статус государственных и соответствующие льготы. В связи с указанными обстоятельствами к середине 2000-х годов уже сложно было сказать о каком-либо точном количестве подобных предприятий.

При этом, имея огромное количество преференций со стороны государства, например государственное имущество или капитал, созданные на средства налогоплательщиков. Такие предприятия не тратили усилий, на создание средств производства, и не были мотивированы на эффективное использование переданных им активов. По сути, имущество таких учреждений оплачивалось налогами граждан, которые в последующем еще оплачивали и их услуги.
Несмотря на радикальную программу сокращения таких предприятий, ситуация только ухудшалась, так как если в 2008 году Федеральная антимонопольная служба возбудила 28 дел в отношении подобных хозяйствующих субъектов, то в 2009-м - уже 72 дела (http://www. rg.ru/2010/06/01/efimov.html).

В связи с тем, что государственные органы наделяли управленческими полномочиями те или иные предприятия, на многих социально значимых рынках товаров и услуг сложилась следующая ситуация. Лица, хозяйствующие на том или ином рынке, конкурирует между собой, а одна компания, которая является таким же участником этого рынка, осуществляет контроль за своими же конкурентами. Получается, что остальные хозяйствующие субъекты уже имеют неравные возможности по доступу на рынок и вынуждены испытывать воздействие со стороны конкурента.

Ярким примером такой ситуации является дело, рассмотренное ФАС РФ в отношении Ростехнадзора. Нарушение заключалось в наделении подведомственных учреждений (ФГУ «ЦЛАТИ») функцией предварительного согласования разрешительной документации, подаваемой участниками рынка в уполномоченный орган. Ростехнадзор ввел обязанность предварительно получить согласование такой документации, причем на платной основе, в подведомственной ему организации.

Схожим примером является расследование ФАС РФ в отношении правительства и Департамента жилищной политики и жилищного фонда г. Москвы, которые передали исполнение ряд государственных функций, связанных с реализацией городских программ по социальной ипотеке и «Молодым семьям - доступное жилье», подведомственным учреждениям. Те, в свою очередь, не только осуществляли эти функции за денежное вознаграждение, но еще и получили гарантированный спрос на свои услуги со стороны граждан.

Указанные нарушения существовали в тех сфеpax, которые связаны с получением разрешений и согласований. Особенно негативное влияние деятельность унитарных предприятий оказала на сферы ЖКХ, транспорта и садово-паркового хозяйства, в сфере бытовых услуг, в «ритуальном бизнесе».

Однако, прежде всего претензии антимонопольного ведомства касались деятельности столичного ГУП «Ритуал». Это предприятие абсолютный монополист в своей сфере, несмотря на то, что действующее законодательство относит похоронное дело к конкурентным отраслям. В связи с ука- 
занными обстоятельствами в 2013 г. началась реорганизация данного учреждения в ходе которой ряд функций должен отойти к бюджетному государственному учреждению, а платные услуги оказываться исключительно на конкурентной основе. В процессе этой реформы до 2018 г. «Ритуал» должен превратиться в государственное бюджетное учреждение. За ним останутся функции ведения архива захоронений, а также оказания ритуальных услуг социально незащищенным слоям населения. Все коммерческие функции отойдут к дочерним структурам.

Несмотря на более чем десятилетнюю реформу деятельности унитарных предприятий и управления государственной собственностью многие из ГУПов и в настоящее время напоминают островки бывшей плановой экономики. Их управленцы не развивают свой основной, официальный вид деятельности, жалуются на невостребованность на рынке в силу низкого качества услуг, но при этом гордятся, что услуги предоставляются по цене ниже себестоимости. В то же время такие предприятия используют дотацию государства в виде предоставления помещений, имущества, земли, субсидий и т. д. При этом, многие унитарные предприятия сдают в аренду находящуюся в их хозяйственном ведении собственность.

На конец 2011 г. в Москве насчитывалось 375 ГУПов. В настоящее время некоторые из унитарных предприятий были упразднены или акционированы. Однако, по сегодняшний день деятельность таких предприятий является одной из самых острых проблем, мешающих развитию конкуренции не только в городе Москве, но и на все территории РФ, о чём неоднократно сообщало ФАС РФ. Государство на протяжении многих лет безуспешно пытается сократить число унитарных предприятий с помощью приватизации. Эксперты считают, что виной тому является то, что предприятия, которые выставляются на продажу, это «неликвиды» - неинтересные хозяйствующим субъектам активы.

Кроме того, со стороны лиц, заинтересованных в сохранении унитарных предприятий идёт активное сопротивление. Несмотря на это, в июне 2013 г. Совет Федерации РФ одобрил поправки в Земельный кодекс, упрощающие изъятие земель у государственных и муниципальных учреждений, а также казенных предприятий. Теперь, в случае неэффективного использования земельного участка, его можно будет изъять во внесудебном порядке. Принимать соответствующие решения уполномочены профильные ведомства (Росимущество,
Минобороны), местные власти, а также правительственная комиссия по развитию жилищного строительства, созданная на базе Фонда содействия развитию жилищного строительства.

В процедуре банкротства сейчас находятся 170 ФГУПов, на каких-либо правах они занимают около 215 тыс. га (почти площадь «большой Москвы»). Всего же в России 2 тыс. ФГУПов, использующих в общей сложности 36 млн га земли (http://www.irn. $\mathrm{ru} /$ articles/35336.html).

При этом, в настоящее время из 70 млн участков не имеют границ 30 млн, а под некоторыми унитарными предприятиями по документам земли вообще нет. Земля под них передавалась в пользование еще в советское время, однако в 1990-2000-е годы далеко не все правообладатели поставили ее на кадастровый учет.

Однако, несмотря на все значительные изменения, следует отметить, что передача государственной собственности от одного юридического лица к другому не изменит ситуацию на том или ином рынке в целом.

Для определения роли и места подобных предприятий в российской экономике необходимо первоначально определить, могут ли с экономической точки зрения такие учреждения заниматься коммерческой деятельностью, а также лишить их преимуществ перед другими юридическими лицами при осуществлении хозяйственной деятельности. Необходимо решить вопрос, на сколько предусмотренный законом механизм управления государственным и муниципальным имуществом позволяет государству решать поставленные задачи по повышению уровня конкуренцию и защите интересов частного бизнеса, могут ли эти задачи решить юридические лица иных организационноправовых форм.

В течение длительного времени унитарные предприятия владели огромными государственными ресурсами, при этом, не имея четкого контроля со стороны государства, и тормозя процесс экономического развития.

Для недопущения подобной ситуации в будущем, необходимо законодательное закрепление процедуры контроля за использованием по назначению и сохранностью переданного имущества, а также возможность привлечения к ответственности в случае выявления допущенных предприятием нарушений.

Кроме того, следует отметить, что в некоторых отраслях унитарные предприятия необходимо оставить. Однако, при этом следует предусмотреть 
в законодательстве механизм распределения ресурсов такому учреждению, а также контроль за их использованием.

Представляется необходимым внести в Федеральный закон от 14.11.2002 N 161-Ф3 «0 государственных и муниципальных унитарных предприятиях» ряд существенных изменений.

Например, необходимо обязать унитарное предприятие перечислять часть своей прибыли по итогам финансово-хозяйственной деятельности за год в соответствующий бюджет. Также, представляется необходимым более четко определить основания изъятия имущества из хозяйственного ведения и оперативного управления. Например, законодательно не закреплены такие понятия как «излишнее» и «неиспользуемое», «используемое не по назначению» имущество, что приводит к произвольному толкованию данных терминов.

В заключение следует отметить, что интеграция унитарных предприятий в рыночную экономику возможна. Основным нюансом в данном вопросе является именно законодательное закрепление положения такого учреждения и контроль за его деятельность со стороны компетентных органов.

В настоящее время о результатах затянувшейся реформы сложно делать какие-либо прогнозы. Однако, необходимо обратить внимание именно на механизм деятельности любого учреждения, подведомственного государственному органу, а не простое «перекладывание из кармана в карман» государственной и муниципальной собственности.

\section{Библиография:}

1. Гражданский кодекс Российской Федерации (часть первая)// КонсультантПлюс;

2. Федеральный закон от 14.11.2002 N 161-Ф3 "О государственных и муниципальных унитарных предприятиях";

3. Унитарные предприятия, учреждения. Право хозяйственного ведения и право оперативного управления: Постатейный комментарий к статьям 113-115, 120 и главе 19 Гражданского кодекса Российской Федерации / П.В. Крашенинников, А.В. Майфат, И.Б. Миронов, и др.; под ред. П.В. Крашенинникова. М.: Статут, 2010.124 с.

4. Муниципальное право России : учебник для бакалавров / С.А. Авакьян, В. Л. Лютцер, Н. Л. Пешин и др.; отв. ред. С.А. Авакьян; Московский государственный университет имени М.В. Ломоносова, Юридический факультет.-Учеб. изд.-М. : Проспект,2013.-544 с.

5. http://www.rg.ru/2010/06/01/efimov.html;

6. http://www.irn.ru/articles/35336.html.

7. Боровков М.С. Комплекс превентивных мер по защите бизнеса от враждебного поглощения // Национальная безопасность / nota bene.-2014.-1.-C. 162-170. DOI: 10.7256/2073-8560.2014.1.10471.

8. Вачугов И.В. Повышение эффективности налогового администрирования как важный фактор ограничения теневой экономики // Налоги и налогообложение.-2013.-10.-C. 782-790. DOI: 10.7256/1812-8688.2013.10.9571.

\section{References (transliterated):}

1. Grazhdanskii kodeks Rossiiskoi Federatsii (chast' pervaya)// Konsul'tantPlyus;

2. Federal'nyi zakon ot 14.11.2002 N 161-FZ "O gosudarstvennykh i munitsipal'nykh unitarnykh predpriyatiyakh";

3. Unitarnye predpriyatiya, uchrezhdeniya. Pravo khozyaistvennogo vedeniya i pravo operativnogo upravleniya: Postateinyi kommentarii k stat'yam 113-115, 120 i glave 19 Grazhdanskogo kodeksa Rossiiskoi Federatsii / P.V. Krasheninnikov, A.V. Maifat, I.B. Mironov, i dr.; pod red. P.V. Krasheninnikova. M.: Statut, 2010. 124 s.

4. Munitsipal'noe pravo Rossii : uchebnik dlya bakalavrov / S.A. Avak'yan, V. L. Lyuttser, N. L. Peshin i dr.; otv. red. S.A. Avak'yan; Moskovskii gosudarstvennyi universitet imeni M.V. Lomonosova, Yuridicheskii fakul'tet.-Ucheb. izd.-M. : Prospekt,2013.-544 s.

5. http://www.rg.ru/2010/06/01/efimov.html;

6. http://www.irn.ru/articles/35336.html.

7. Borovkov M.S. Kompleks preventivnykh mer po zashchite biznesa ot vrazhdebnogo pogloshcheniya // Natsional'naya bezopasnost' / nota bene.-2014.-1.-C. 162-170. DOI: 10.7256/2073-8560.2014.1.10471.

8. Vachugov I.V. Povyshenie effektivnosti nalogovogo administrirovaniya kak vazhnyi faktor ogranicheniya tenevoi ekonomiki // Nalogi i nalogooblozhenie.-2013.-10.-C. 782-790. DOI: 10.7256/1812-8688.2013.10.9571. 